\title{
RESEARCH OF INFLUENCE OF STEEL 4X5MФC ION NITRIDING PROCESS PARAMETERS ON CHARACTERISTICS OF NITRIDED LAYER
}

\author{
Mihail Bosyakov $^{1}$, Sergei Sakhanko ${ }^{2}$, Mihail Niaroda ${ }^{2}$ \\ ${ }^{1}$ Physics and Technology Institute of National Academy of Sciences of Belarus; \\ ${ }^{2}$ Baranovichi State University, Belarus \\ plasma.by.metal@gmail.com; one1sergei@mail.ru; nerodamv@tut.by
}

\begin{abstract}
At the present time an emerging trend for industrially developed countries is towards a wide use of ion nitriding as a method of low-temperature thermochemical hardening processing of machine components, cutting and stamping tools. To a large extent the reason for it is high-tech automated equipment - ion nitriding chamber that solved such disadvantages of gas nitriding as long processing time, fragility of nitration case, low back-toback endurance, process complexity and instability of the results. Due to its advantages nitriding is widely used in all industrially developed countries. However, the possibilities of this thermochemical treatment implying a variety of structural and phase features of nitrided cases are not used on a full scale. Research teams and scientists from all over the world do researches on nitriding technologies to develop new nitrided materials with new properties. Specific usage conditions need controlled nitriding technologies that allow building diffuse layers of different phase composition and structure, which determines the working capacity concerning wear, corrosion, reversed loads, creep-resistance under an elevated temperature. Therefore, it is very important to develop different technologies that allow getting the specifically required structure and phase composition of the nitrided layer that guarantee best performance of products. The aim of the present work is to study steel 4Х5МФС ion nitriding process depending on the process variable - chemical activity of glow-discharge. Considering that this steel is preferably used in production of tools for processing of materials in hot condition, according to that the nitrided case should be fully diffusive, without the white layer of iron nitride on the surface. Special attention is paid in this article to the study of nitriding mode issues, in particular, to the processing temperature, nitrogen content in the gas mixture and processing time. As for today, the tendency to nitriding at low $\left(400-550^{\circ} \mathrm{C}\right)$ temperatures is observed. Rational nitriding time is determined based on the required hardness and thickness of the nitrided layer. However, the difficulty in applying the ion-plasma nitriding method is due to the insufficient study of the workpiece surface saturation process, as well as to the lack of methods for selection of technological processing regimes. It should also be noted that due to the wide possibilities of regulating the ion-plasma nitriding regimes, further study of the ion-plasma nitriding technology is reasonable.
\end{abstract}

Keywords: hardening, ion nitriding, depth, hardness, steel, machine parts, equipment, nitrided layer.

\section{Introduction}

At the present time an emerging trend for industrially developed countries is towards a wide use of ion nitriding as a method of low-temperature thermochemical hardening processing of machine components, cutting and stamping tools. [1-6]. To a large extent the reason for it is high-tech automated equipment - ion nitriding chamber that solved such disadvantages of gas nitriding as long processing time, fragility of nitration case, low back-to-back endurance, process complexity and instability of the results.

Ion nitriding unit consists of a working chamber, power supply system, vacuum system and cooling system. Depending on the type of the processed products, vacuum chambers can be chambertype, bell-type, vertical retort-type, door-type or section-type.

Modern ion nitriding machines have two main varieties. The first one has cold-wall working chambers cooled by water (e.g., machines produced by Belarusian "ФТИНАНБ”, Bulgarian company "IONITECH", and also some Brazilian companies) [7]. It should be noted that chambers with screen insulation should be considered as passively hot-wall chambers, because the wall (screen) temperature cannot be controlled independently and depends on the batch temperature. The second type is chambers with so-called hot walls that have additional heating resistors inside or outside of the main wall. These are the active hot-wall chambers. This type of equipment is produced by German companies ELTRO, PlaTeg and Austrian company RÜBIG.

Due to its advantages nitriding is widely used in all industrially developed countries. However, the possibilities of this thermochemical treatment implying a variety of structural and phase features of nitrided cases are not used on a full scale. Research teams and scientists from all over the world do researches on nitriding technologies to develop new nitrided materials with new properties. 
Working temperature, nitriding time, working pressure, composition and flowrate of working gas mixture are the main technology factors that influence the efficiency of ion nitriding.

Specific usage conditions need controlled nitriding technologies that allow building diffuse layers of different phase composition and structure, which determines the working capacity concerning wear, corrosion, reversed loads, creep-resistance under an elevated temperature. Therefore, it is very important to develop different technologies that allow getting the specifically required structure and phase composition of the nitrided layer that guarantee best performance of products.

Despite rather wide usage of ion nitriding in industry, including Belarusian companies (MAZ, BelAZ, MZKT, OJSC "Gomselmash", OJSC "Mogilevliftmash", Tehnolit, etc.), academic literature has lack of information concerning implementation of controlled treatment of different steel grades. This slows down the expansion of the variety of nitrided products, especially hardening of parts from alloyed tool steel for die tooling and casting tooling.

Conventionally gas and ion nitriding form multilayer diffuse coatings consisting of an external nitrided surface and a diffuse underlayer (internal nitriding coating). Concerning the performance, each layer has its own functions. Nitrided coating provides resistance to wear and corrosion and the internal layer provides creep-resistance, fatigue resistance under an elevated temperature, resistance to dynamic wear and mechanical impact. However, there are no specific recommendations in academic literature on how to implement this on a particular industrial machine.

The aim of the present work is to study the steel 4X5МФC ion nitriding process depending on the process variable - chemical activity of glow-discharge. Considering that this steel is preferably used in production of tools for processing of materials in hot condition, according to [1-6] the nitrided case should be fully diffusive, without the white layer of iron nitride on the surface.

\section{Materials and methods}

The research was carried out using the ion nitriding furnace with a door-type chamber, model УА-25-400/400 produced by "ФТИНАНБ", located in ion nitriding laboratory of the Baranovichi State University. The furnace has a vacuum chamber with passive cold walls and the following specifications: cathode diameter $-400 \mathrm{~mm}$, loading height $-400 \mathrm{~mm}$ (Fig. 1).

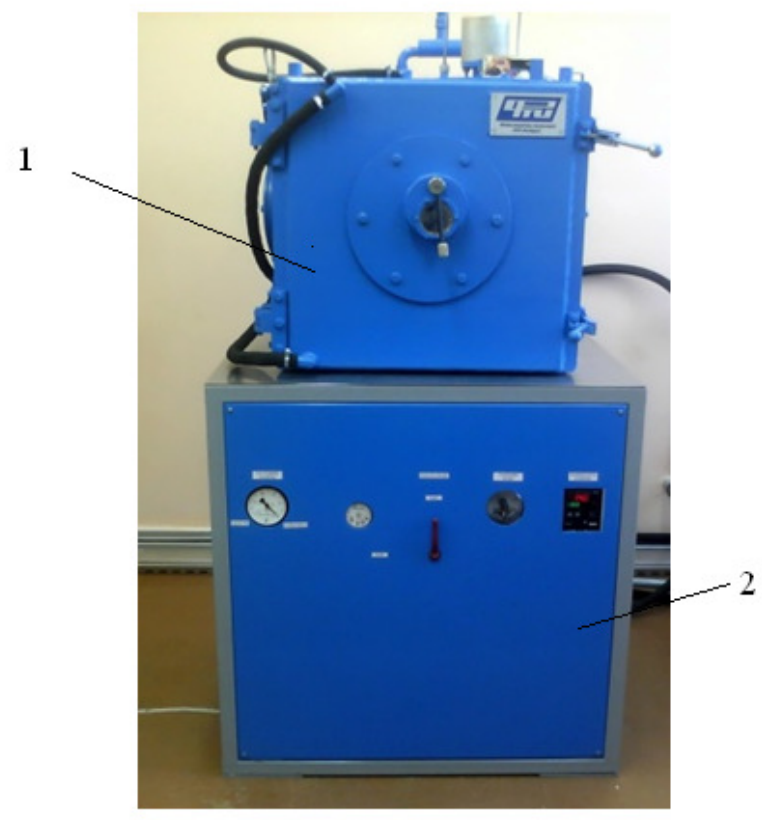

Fig. 1. Ion nitriding furnace: 1 - working chamber; 2 - cooling system

Research works [8; 9] show that effective ion nitriding process control on industrial equipment requires knowledge of interrelation of the discharge power and gas pressure depending on the processed batch, because the power (discharge current and voltage) determines not only the batch 
heating and heat retention during the holding stage, but it also determines the chemical activity of a discharge, i.e. its "nitriding capacity".

During ion nitriding molecular nitrogen (or ammonia) in glow-discharge turns directly into reactive nitrogen (i.e., nitrogen that can react with metal). This simplifies the understanding of how it is possible to influence on the reactivity of nitrogen in plasma. It is subject to the gas phase composition (nitrogen and other gas components ratio) and electric values of the discharge (first of all current density) $[9 ; 10]$.

While setting the mode of ion nitriding it is necessary to be guided by the following rules [10]:

1. If it is possible to determine the core hardness that is defined by the previous drawback, then it is possible to set the nitriding temperature to at least $20^{\circ} \mathrm{C}$ lower than the drawback temperature. If this temperature provides the surface hardness according to the engineering documentation, then the holding stage can be carried out with such temperature. It is important to remember that the hardness growth after nitriding significantly depends on the temperature: the higher the temperature, the lower the hardness. Additionally, with higher temperature there is a higher possibility of geometric distortion of the parts, especially if they have complex geometry. Therefore, the temperature range of ion nitriding falls within $500-550{ }^{\circ} \mathrm{C}[1-6]$, which is actually acceptable for most constructional and tool steel grades.

2. The choice of the processing temperature determines electric power of discharge that will take place during the isothermal hold stage, as well as determines the current density if the batchsurface is known. And current density of discharge depends on the chamber pressure and gas composition.

3. From [1-6; 11] it is known that during batchheating and at the beginning of the holding stage under high nitrogen flow rate the solid "white" layer of iron nitride is formed, which slows down nitrogen entry into the metal significantly. Therefore, the heating and holding should be carried out in such way as to avoid early the white layer formation. According to [12], the "critical" nitrogen flow rate parameter can be deduced from A.Fick equation for diffusion for boundary condition $x=0$ (metal surface):

$$
\Pi_{N}=\frac{C_{\alpha-F e} \cdot \sqrt{D_{\alpha-F e}}}{\sqrt{\tau}},
$$

where $C_{\alpha-F e}-$ nitrogen solubility in alloyed $\alpha$-solid iron solution;

$D_{\alpha-F e}-$ nitrogen diffusion coefficient in alloyed $\alpha$-solid iron solution depending on the temperature;

$\tau$ - time.

In this case $\tau$ is the period of time during which nitrogen is absorbed by the surface and diffuses into the metal without forming a solid nitrided layer. According to nitriding models [1-6], at the beginning nitrogen merges into $\alpha$-solid iron solution, then nitrides of alloying agents are formed and after that a layer of iron nitrides starts to build up (the "white layer" that significantly slows down nitrogen entry from gas phase into the metal). In this way the parameters of the processed material, solubility of nitrogen and the diffusion coefficient, as well as the processing time determine the choice of the required nitrogen flow rate to be provided by the glow-discharge - in order to form a diffusive layer without the iron nitride layer.

The study [13] shows information about the influence of alloying agents of steel on the values $C_{\alpha-F e}$ and $D_{\alpha-F e}$ of nitrogen in $\alpha$-phase of the steel and the methods to calculate these parameters:

$$
\left.C_{\alpha-F e}=\exp \left(\frac{-4575}{T}+3\right) * 10^{-\left(K_{i}^{(}\left(n_{i}\right)\right.}+\ldots+K_{n}^{\left(n_{n}\right)}\right),
$$

where $K_{i}^{\left(n_{i}\right)}$ - alloying agent activity coefficient.

$$
D_{\alpha-F e}=D_{0} * \exp \left[\frac{B_{i}^{\left(n_{i}\right)}+\ldots+B_{n}^{\left(n_{n}\right)}}{T}\right],
$$


where $B_{i}^{\left(n_{i}\right)}$ - alloying agent influence coefficient;

$D_{O}$ - coefficient of diffusion in pure Armco iron [14].

4. Based on the chemical composition of steel, of which the processed parts are made, it is possible to calculate the complex: $C_{\alpha-F e}{ }^{\text {лez }} \cdot \sqrt{ } D_{\alpha-F e}{ }^{\text {лег }}$ (solubility $\mathrm{x}$ root of diffusion) as a function of temperature.

The calculated value of the complex $C_{\alpha-F e}{ }_{\text {nez }} \cdot \sqrt{ } D_{\alpha-F e}^{\text {nez }}$ will determine the composition of saturating environment (percentage of nitrogen) during the heating and at the first steps of the holding stage to prevent an early forming of the "white" nitride layer that slows down the diffusion of nitrogen into the metal, i.e. the nitrogen flow rate $\Pi_{N 2}\left(\mathrm{~L} \cdot \mathrm{h}^{-1} \cdot \mathrm{m}^{2}\right)$, provided by the discharge should be equal to the calculated using (1).

Thus, the calculated value of nitrogen solubility and the diffusion coefficient allow to choose the processing time and nitrogen flow rate in such a way that the iron nitride layer could be formed neither during the heating nor at the beginning of the holding stage.

If we assume that the main source of atomic ("reactive") nitrogen is the process of dissociative recombination of molecular ion $N_{2}^{+}$on the surface [2], then the nitrogen flow rate on the surface can be quantitatively represented in the following way $[9,10]$ :

$$
\Pi_{N_{2}} \frac{L}{h} \cdot m^{2}=0.897 \cdot J,\left(\mathrm{~A} \cdot \mathrm{m}^{2}\right) \cdot\left(\% N^{2}\right)
$$

where 0.897 is the coefficient of proportionality;

$J$ - discharge current density;

$\% \mathrm{~N}_{2}$ - percentage of nitrogen in gas mixture.

Typical parameters for the nitriding process on industrial equipment are: current density usually 2.5-12 A $\cdot \mathrm{m}^{-2}$, nitrogen percentage in the mixture is $25-75 \%$. Consequently, the nitrogen flow rate under such settings is from 0.54 to $7.78 \mathrm{~L} \cdot \mathrm{h}^{-1} \cdot \mathrm{m}^{2}$. During the first saturation period of nitriding an active absorption of nitrogen by the surface is observed and gas environment sometimes is not able to refill the number of active nitrogen atoms diffusing into the metal on time. Later, along with reduction of the diffusion speed due to concentration gradient decrease, the concentration of active nitrogen in the gas phase increases. This is especially evident while processing a large surface batch [9]. That is why the percentage of nitrogen is usually reduced comparing to the initial level as the processed batch becomes more saturated.

Experiments on steel 4X5МФC nitriding were carried out in the following way: in addition to the study samples, the chamber was loaded by repeatedly nitrided parts in order to prevent nitrogen absorption by the batch.The processed samples are made of 4 X $5 \mathrm{M} \Phi \mathrm{C}$ steel and have the following

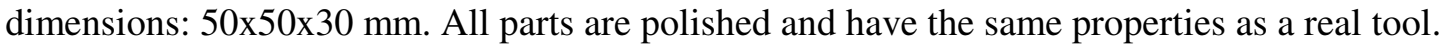

Thus, knowing the surface area of the batchand and the current density on the holding stage it is possible to calculate the maximum nitrogen flow rate, i.e. nitriding ability of the discharge:

$$
\Pi_{N_{2}} \frac{L}{h} \cdot m^{2}=0.897 \cdot J,\left(\mathrm{~A} \cdot \mathrm{m}^{2}\right) \cdot\left(\% N^{2}\right)
$$

Preliminary, formulae (1-3) were used; they include information about the chemical composition of steel "4ХМФС" and results from the studies $[13,14]$. These formulae were used to calculate the parameter for temperature $545^{\circ} \mathrm{C}$, which turned to be $1.05\left(\mathrm{~L} \cdot \mathrm{h}^{-1} \cdot \mathrm{m}^{2}\right)$ for the first hour of holding. I.e., according to the calculations if the discharge provides such flow rate, then the nitrided layer will be formed without the nitride "white layer". Otherwise in the first hours of holding we get a nitride layer that will slow down the forming of the inner nitriding zone.

Therefore, choosing the holding mode, it is necessary to set the values $\Pi_{N 2}\left(\mathrm{~L} \cdot \mathrm{h}^{-1} \cdot \mathrm{m}^{2}\right)$ close to the calculated.

In order to get the right depth of the layer the required time is to be selected. Generally, at the processing temperature of $540-545^{\circ} \mathrm{C}$ during $15-16$ hours the steel $4 \mathrm{X} 5 \mathrm{M} Ф \mathrm{C}$ receives a nitrided layer of $0.25 \mathrm{~mm}$ depth, which corresponds to the engineering documentation requirements for most 
products made of this steel. It should be noted that the best capacity is provided by the layer with a smooth distribution of hardness from the surface of the part to its core, and this can be achieved by nitriding at the temperature of $540-5600^{\circ} \mathrm{C}[5 ; 6]$.

Thus, the relationship between the chemical activity of the discharge (determined by the current density and the consumption of nitrogen) with the characteristics of the nitrided steel (the solubility of nitrogen in the $\alpha$-solid solution and the diffusion coefficient), is as follows:

$$
\left(\% N_{2}\right)=\frac{C_{\alpha-F e^{\text {leg }}} \cdot \sqrt{D_{\alpha-F e^{\text {leg }}}}}{J \cdot x \cdot \sqrt{\tau}} .
$$

If a working mixture consisting of nitrogen, argon and hydrogen is used, the total gas flow rate and the hydrogen consumption can remain unchanged step-by-step - only the consumption of nitrogen and argon changes depending on the area of the batchand current density, or only nitrogen consumption changes (and its percentage in the mixture).

Based on the results of flow rate calculations for 4X5МФC steel, the following treatment mode was chosen at a temperature of $545^{\circ} \mathrm{C}$ :

- Step 1: nitrogen flow rate $-\Pi=3.321 \cdot \mathrm{h}^{-1} \cdot \mathrm{m}^{2}$, duration -0.5 hour,

- Step 2: nitrogen flow rate $-\Pi=2.07 \mathrm{l} \cdot \mathrm{h}^{-1} \cdot \mathrm{m}^{2}$, duration -5.5 hours,

- Step 3: nitrogen flow rate $-\Pi=1.48 \mathrm{l} \cdot \mathrm{h}^{-1} \cdot \mathrm{m}^{2}$, duration -5.0 hours,

- Step 4: nitrogen flow rate $-\Pi=1.88 \mathrm{l} \cdot \mathrm{h}^{-1} \cdot \mathrm{m}^{2}$, duration -5.0 hours.

The current density is determined by dividing the discharge current by the area of the batchand end of either the last stage of the heating of the batch, or the first stage of holding. For a more accurate determination of the current density at the last step of holding, it is recommended to limit the heating rate to a value of $0.1 \ldots 0.2$ degrees per minute. The area of the batch consists of the area of loaded parts and the area of the mounting (if one is used).

Figure 2 shows the microhardness distribution over the depth of the nitrided layer, and in Figure 4 the structure of the nitrided layer is shown:

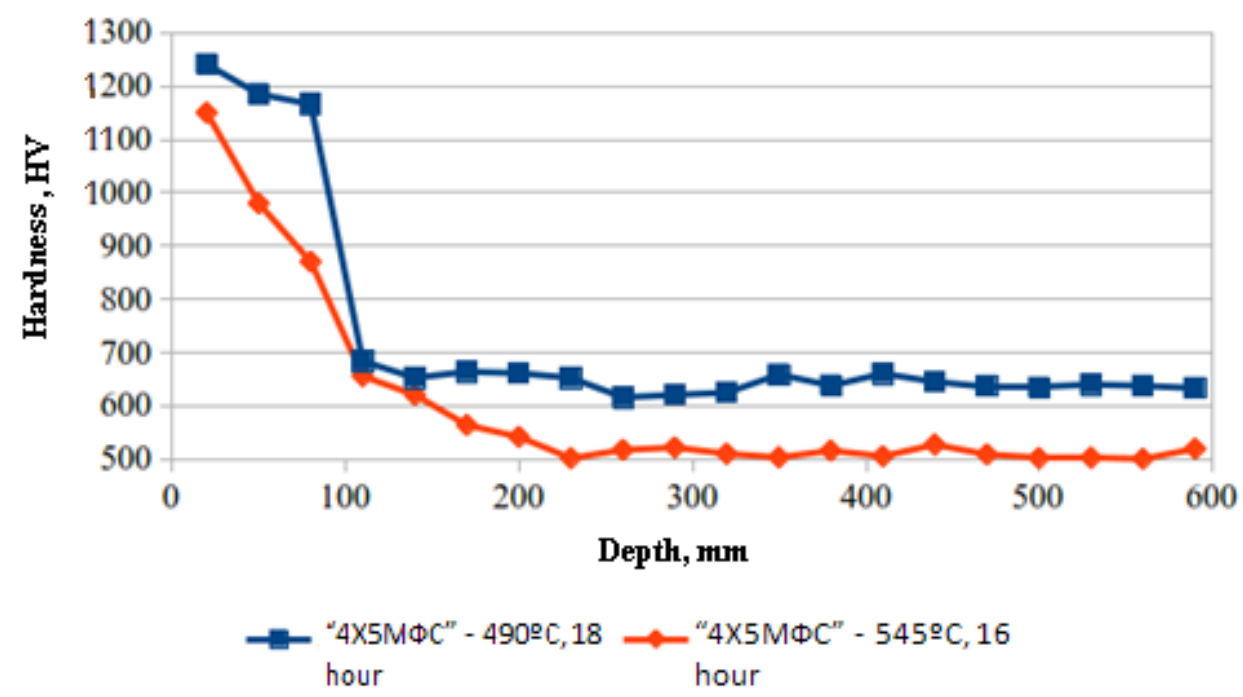

Fig. 2. Distribution of microhardness along the depth of the nitrided layer

The microhardness measurements were carried out on a digital microhardness meter AFFRIMVDM8 (Italy) using the Vickers method and with precision $\pm 15 \mathrm{HV}$ under the load of $100 \mathrm{~g}$ (Fig. 4). Figures 2 and 3 show that the nitrided layer has a fairly smooth transition of hardness from the surface to the core and does not have a solid white nitride layer. Treatment at a lower temperature $\left(490{ }^{\circ} \mathrm{C}\right)$ gives a sharper transition of hardness - parts with such a nitrided layer are more suitable for operation in abrasive wear without impact loads [3; 4]. 


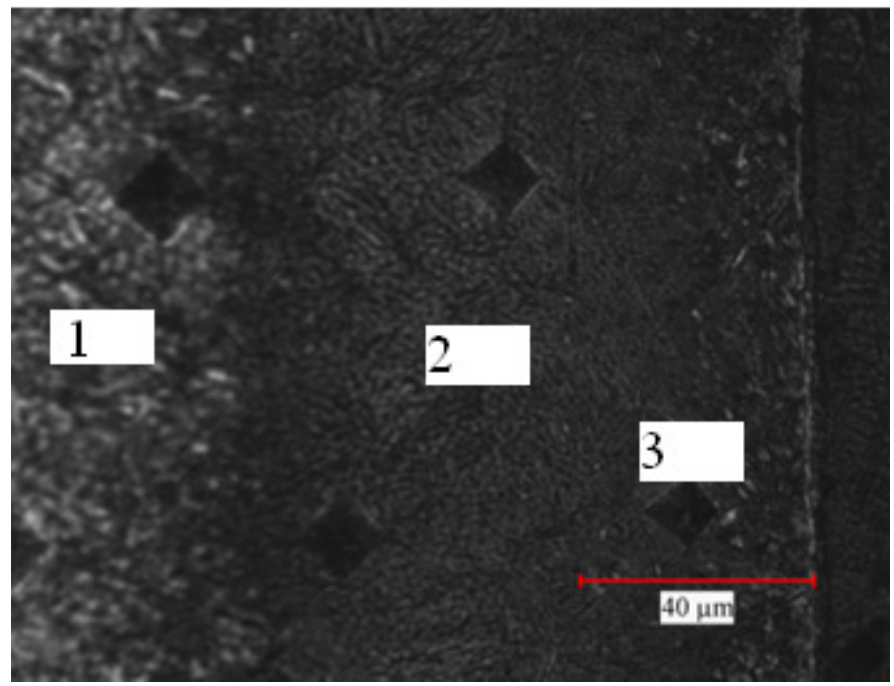

Fig.3. Structure of nitrided layer: 1 - steel; 2 - nitrided layer; 3 - nitride layer

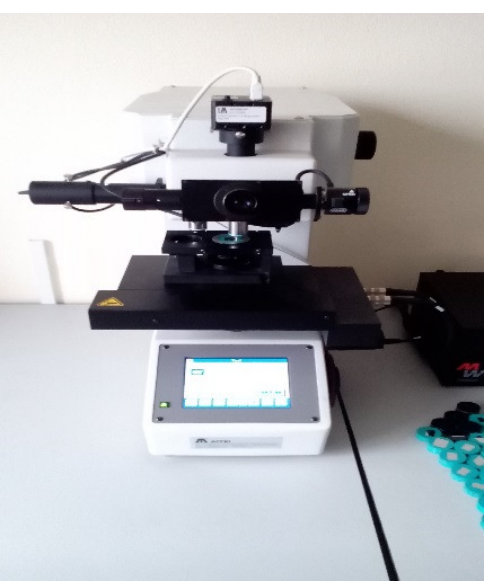

Fig. 4. Microhardness meter AFFRI-MVDM8

\section{Conclusions}

Ion nitridation, as the most effective method of nitriding, allows reduction of the saturation time, reduction of the processing temperature and thus reduction of the formation of the brittle $\varepsilon$-phase in the surface layer, up to its complete absence. Viscous, shock-resistant surface layers obtained by ion nitriding are especially important in forging and die production, significantly increasing the service life of tools. Stamp steel 4X 5ФMC is nitrided at a temperature of $420-540{ }^{\circ} \mathrm{C}$. The choice of these temperatures is guided by the need to obtain high hardness and wear resistance of the nitrided layer, which are obtained due to dispersed nitrides precipitation. Knowing the steel grade, processing temperature and processed surface area, it is possible to make the necessary calculations.

Thus, the studies show that, when nitriding 4X5MФCsteel, setting the treatment mode with nitrogen flow range close to the calculated one for a given temperature provides a predictable production of a nitrided layer with specified parameters.

\section{References:}

1. Берлин Е.В., Коваль Н.Н., Сейдман Л.А. Плазменная химико-термическая обработка поверхности стальных деталей. М.: Техносфера, 2012. - 464 с. (In Russian)

2. Пастух И.М. Теория и практика безводородного азотирования в тлеющем разряде.Харьков: ННЦ ХФТИ, 2006. - 364 с. (In Russian)

3. Арзамасов Б.Н., Братухин А.Г.. Елисеев Ю.С., Панайоти Т.А. Ионная химико-термическая обработка сплавов:- М.:Изд. МГТУ им. Баумана, 1999. - 400 с. (In Russian)

4. Лахтин Ю.М., Коган Я.Д., Шпис Г., Бемер 3. Теория и технология азотирования:- М.: «Металлургия», 1991. - 320 c. (In Russian)

5. Азотирование и карбонитрирование. Чаттерджи-Фишер Р., Эйзелл Ф., пер. с нем./под ред. СуповаА.В.. М.: «Металлургия»,1990. - 280 с. (In Russian)

6. David Pye. Practical Nitridind and FerriticNitrocarburizing, 2003, ASM International Park, Ohio.

7. Puls-Plasma nitriding Units - www.nitrion.com.br.

8. Босяков М.Н., Козлов А.А. Энергетические параметры процессов ионного азотирования на промышленном оборудовании / Доклады БГУИР, 2013, № 3(73), с. 76-82. (In Russian)

9. Bosyakov M.N., Kozlov A.A., Pobol I.L. Nitrogen transfer during ion nitriding, Surface Engineering, 2015, 3, pp. 3-10.

10. Босяков М.Н., Моисеенко А.Н. Выбор режима упрочняющей обработки на установках ионного азотирования промышленного типа. Сборник научных трудов «Современные методы и технологии создания и обработки материалов». В 3 кн. Кн. 2. - Минск: ФТИ НАН Беларуси, 2016 г. - С. 50-58. (In Russian) 
11. Азотный потенциал: современное состояние проблемы и концепция развития // Зинченко В.М., Сыропятов В.Я., Прусаков Б.А., Перекатов Ю.А. / Под общей редакцией и с предисловием д. т. н. проф. Б.А. Прусакова. - М.: ФГУП «Издательство «Машиностроение», 2003. - 90 с. (In Russian)

12. Y. Sun, T. Bell. Computer Prediction of TheresholdNitriding Potential Curves. Heat Treatment of Metals, 1997,№2, pp. 43-49.

13. Лахтин Ю.М., Коган Я.Д., Булгач А.А. Расчет влияния легирующих элементов на растворимость и диффузию азота в стали при азотировании в $\alpha$ и $\varepsilon-$ фазах. Труды МАДИ. Азотирование в машиностроении, выпуск 174, M. 1974, c.42-59. (In Russian)

14. Hosseini S.R., Ashrafizaden F., Kermanpur A. Calculation and experimentation of the compound layer thickness in gas and plasma nitriding of iron. Iranian Journal of Science and Technology, 2010, v.34, №B5, p.553-566. 